\title{
Adopting an Ecosystem Approach: Local Variability in Remedial Action Planning
}

Wendy A. Kellogg

Cleveland State University, w.kellogg@csuohio.edu

Follow this and additional works at: https://engagedscholarship.csuohio.edu/urban_facpub

Part of the Ecology and Evolutionary Biology Commons, and the Natural Resources Management and Policy Commons

How does access to this work benefit you? Let us know!

Publisher's Statement

(c) 1998 Taylor \& Francis (Routledge)

\section{Original Citation}

Kellogg, W. A. (1998). Adopting an ecosystem approach: Local variability in.. Society \& Natural Resources, 11(5), 465-483.

\section{Repository Citation}

Kellogg, Wendy A., "Adopting an Ecosystem Approach: Local Variability in Remedial Action Planning" (1998). All Maxine Goodman Levin School of Urban Affairs Publications. 012369.

https://engagedscholarship.csuohio.edu/urban_facpub/69

This Article is brought to you for free and open access by the Maxine Goodman Levin School of Urban Affairs at EngagedScholarship@CSU. It has been accepted for inclusion in All Maxine Goodman Levin School of Urban Affairs Publications by an authorized administrator of EngagedScholarship@CSU. For more information, please contact library.es@csuohio.edu. 


\title{
ADOPTING AN ECOSYSTEM APPROACH: LOCAL VARIABILITY IN REMEDIAL ACTION PLANNING
}

\author{
Wendy A. Kellogg, Cleveland State University
}

\begin{abstract}
Through the 1970s and 1980s Great Lakes scientists advocated adoption of an "ecosystem approach" as a framework for water quality policy, including development of remedial action plans (RAPs) for the 43 areas of concern in the Great Lakes basin. RAPs are developed by state and provincial environmental or resource agencies, often in consultation with local stakeholder or citizen advisory committees. The International Joint Commission's guidelines for adopting an ecosystem-based approach describe the need for more integrative conceptual frameworks, interdisciplinary information, and flexible institutional arrangements. This article describes adoption of an ecosystem approach by lead agencies in two RAPs, where adoption was shaped by a constellation of organizational differences and contextual variables. In both, a community-based RAP committee played an important role.
\end{abstract}

By the late 1970s, Great Lakes scientists and policymakers realized that the goal of the 1972 Great Lakes Water Quality Agreement (the Agreement) to "restore and maintain the chemical, physical and biological integrity of the Great Lakes Basin Ecosystem" would require a new planning and management framework. That framework, an "ecosystem approach," was adopted by Canada and the United States in the 1978 amendments to the Agreement. The International Joint Commission (IJC), the binational organization that oversees water quality management initiatives in the Great Lakes basin, developed principles and guidelines for implementing an ecosystem approach. This article analyzes the extent that this planning and management innovation was adopted by lead agencies and stakeholders developing remedial action plans (RAPs) for areas of concern. The article first summarizes key aspects of the IJC's articulation of what an ecosystem approach should entail and then presents a set of variables that would be expected to either impede or support adoption of an ecosystem approach as a planning and management innovation. The article focuses on the extent to which lead agency adoption includes an integrated conceptual and information base and the institutional changes that accompany this integration. For two RAP processes the level of congruence with the IJC approach and how the adoption process occurred is described. How variability in local conditions shaped the innovation adoption process is demonstrated.

\section{An Ecosystem Approach as an Innovation in Great Lakes Decision Making and Planning}

Although an ecosystem approach was not specifically defined in the 1978 Agreement Amendments, Great Lakes scientists and policymakers have offered numerous

Address correspondence to Wendy A. Kellogg, Maxine Goodman Levin College of Urban Affairs, Cleveland State University, 1737 Euclid Avenue, Cleveland, OH 44115, USA. 
guidelines on what an ecosystem approach is, both normatively and operationally. An ecosystem approach is both a framework for planning and management decisions and a process by which decisions are made. An ecosystem approach calls for a conceptualization of the basin as a unified system demarcated by its natural watershed boundaries. Understanding that system and developing effective policies are based on principles of ecosystem integrity and an assumption that the system is self-sustaining (MacKenzie 1993). The ecosystem approach also calls for humans to consider themselves part of the ecosystem when considering its function, adopting a "man-in-a-system" rather than a "system-external-to-man concept" (IJC 1978). Such an approach implies that management strategies would attempt to reconcile societal values and economic activities with the ecological carrying capacity of the Great Lakes ecosystem (National Research Council and Royal Society of Canada 1985; Great Lakes Science Advisory Board [GLSAB] 1989).

By 1985 , scientists had made significant strides in developing the ecosystem approach in concept and principle, but implementation was in the exploratory state, "chiefly regarding efforts to obtain the information base (mapping and monitoring) upon which ecosystem strategies depend" (Caldwell 1988, 6). Scientific analysis to guide planning and management would be based on a cross-disciplinary knowledge base, integrating consideration of water, land, and air as media with the knowledge of how human activities affect media conditions (Pollution from Land Use Activities Reference Group 1978; National Research Council and the Royal Society of Canada 1985). Scientists were asked to provide knowledge in such a way to model the dynamic and reciprocal relationship between media conditions and human action, to mirror the complexities of the basin ecosystem dynamics (GLSAB 1978).

Achieving an integrative and holistic knowledge base inherent to implementing the ecosystem approach would require changes in institutional arrangements, including increased interagency cooperation and flexibility (GLSAB 1989; Hartig and Law 1994) and participation by a wide variety of stakeholders and citizens in consensus-based decision making processes. These changes were needed to incorporate evolving socioeconomic realities and scientific understanding (GLSAB 1978, 29; Yarbrough 1985) as well as to build public support for continued scientific analysis and policy implementation.

\section{An Ecosystem Approach for Remedial Action Plans}

The International Joint Commission designated 43 areas of concern in the basin, the bays and rivers with the worst degradation of water quality, and a significant source of pollutants to the near-shore waters and the open lakes. As part of their responsibilities under the Agreement, the United States and Canada and the state and provincial governments in the basin agreed to develop RAPs to restore the 14 "beneficial uses" of the waters deemed impaired in each area of concern. The 1978 update to the Agreement stated that RAPs "shall embody a systematic and comprehensive ecosystem approach to restoring and protecting beneficial uses in Areas of Concern" (IJC 1989, 32).

What might an ecosystem approach for a RAP entail? Adopting an ecosystem approach would require three changes: reframing the planning problem, creating an integrative knowledge base, and institutionalizing multi-stakeholder participation in decision making. A reconceptualization of RAPs from a simple water quality improvement plan to a watershed-based management plan would take the full range of human activities as these affect water quality into account. Management stra- 
tegies would not only address remedial actions to restore degraded conditions, but would also focus on changing human behavior through policies and practices to allow the watershed ecosystem to function properly in perpetuity. Developing these strategies would require a fully integrative understanding of the watershed's biochemical and physical function and the stresses caused by humans. Such an understanding, and implementation of remedial management actions to change conditions, would require the full cooperation and participation of all jurisdictions, regulatory and resources agencies, and other stakeholders and citizens in the watershed.

In 40 of the 43 RAPs, the lead agencies have been joined by either an advisory or multi-stakeholder committee from the community to assist in the planning process (Landre et al. 1990; Hartig and Law 1994). These committees typically consist of representatives of local and regional government, industry, commerce, fishing clubs, environmental and civic organizations, farming associations, and university academics (Landre and Knuth 1993; Kellogg 1993). Two leading Great Lakes researchers (and RAP participants) asserted that "the key to implementing an ecosystem approach is establishing a basin committee ... broadly representative of social, economic and environmental interests within the affected area [of concern]" (Hartig and Vallentyne 1989, 425). In what way would such a committee be key? The community-based committee would improve the knowledge used for decision making and increase the likelihood that recommendations of the RAP would be implemented through political mobilization.

Others have described institutional and technical challenges or preconditions to using an ecosystem approach (Dockstator 1990; MacKenzie 1993). This current study analyzed use of an ecosystem approach as an innovation in framing and creating the information based used to developed the draft RAP. The study was guided by three questions: (1) To what extent have lead agencies adopted integrated conceptual and informational needs of an ecosystem approach as it had been articulated by the IJC to guide their development of RAPs? (2) What organizational and contextual variables influenced how an ecosystem approach has been adopted? (3) What role have citizen advisory and stakeholder committees played?

\section{Theoretical Framework: Adoption of Innovation}

Adoption of an innovation by an organization occurs in two stages-initiation and implementation. The initiation stage consists of two substages-agenda setting (the organization members perceive that an innovation is needed) and matching (the innovation is "test-run" for its feasibility and appropriateness for the organization). The implementation stage consists of three substages-redefining (the innovation is reinvented to accommodate the organization's needs and structure more closely), clarifying (the innovation is gradually put to wider use and the "meaning of the new idea becomes clearer to the organization's members"), and routinizing (the innovation becomes incorporated into the regular activities of the organization) (Rogers 1983, 362-365).

The signing of the Great Lakes Water Quality Agreement in 1978 calling for ecosystem management and the 1985 amendments calling for use of an ecosystem approach to guide preparation of remedial action plans for the areas of concern constituted the agenda-setting stage, and changed the external environment of the basin's resource management and environmental protection agencies responsible for 
TABLE 1 Variables influencing adoption of an ecosystem approach by RAP organizations.

\begin{tabular}{|c|c|}
\hline Variables & Hypotheses \\
\hline $\begin{array}{l}\text { Locus of } \\
\text { impulse }\end{array}$ & $\begin{array}{l}\text { Adoption is enhanced if the impulse comes from within } \\
\text { the organization (Dalziel and Schoonover 1988) or if } \\
\text { room for ownership of the idea by those responsible for } \\
\text { its adoption exists (Burch and DeLuca 1984). The } \\
\text { presence of an external change agent with a high level of } \\
\text { orientation to change or activism can catalyze the } \\
\text { agency to action (Rogers and Shoemaker 1971; Zaltman } \\
\text { et al. 1973; Spence 1994). }\end{array}$ \\
\hline Compatibility & $\begin{array}{l}\text { Organizations tend to more readily adopt an innovation } \\
\text { that mirrors the existing structure or function of the } \\
\text { organization (Zaltman et al. 1973; Dalziel and Schoonover } \\
\text { 1988). Differences in legal institutions as these } \\
\text { shape agency authority will dictate responses to innovation } \\
\text { (Hall 1987). An organization may attempt to mold } \\
\text { the innovation to existing programs (King and Anderson } \\
\text { 1995) or may change its structure in response to the } \\
\text { innovation (Rogers 1983). }\end{array}$ \\
\hline $\begin{array}{l}\text { Technical } \\
\text { expertise }\end{array}$ & $\begin{array}{l}\text { Scientists in bureaucracies are traditionally organized } \\
\text { according to discipline or program and expertise is } \\
\text { generally concentrated in a single bureau (Desveaux } \\
\text { et al. 1994). Greater technical or institutional complexity } \\
\text { required for implementing an innovation will deter adoption } \\
\text { (Zaltmann et al. 1973; Desveaux et al. 1994). }\end{array}$ \\
\hline Process skills & $\begin{array}{l}\text { Variability in process style or skills of lead agency staff } \\
\text { or facilitators may affect the level of consensus } \\
\text { among RAP participants regarding the need to adopt } \\
\text { an ecosystem approach (Susskind and Cruikshank 1987). }\end{array}$ \\
\hline $\begin{array}{l}\text { Agency } \\
\text { organizational } \\
\text { slack }\end{array}$ & $\begin{array}{l}\text { Adoption of an innovation can result from "organizational } \\
\text { slack," an abundance of money, personnel, or } \\
\text { expertise that allows some degree of experimentation } \\
\text { beyond established responsibilities of an } \\
\text { organization (Mohr 1969; Rogers 1983). }\end{array}$ \\
\hline $\begin{array}{l}\text { Stakeholder } \\
\text { technical } \\
\text { expertise }\end{array}$ & $\begin{array}{l}\text { If citizen participants lack knowledge or skills to understand } \\
\text { scientific evidence, they will be less able to } \\
\text { articulate their preferences to agency staff who may not } \\
\text { understand how to integrate values on demands, but } \\
\text { who may respond to technically based arguments } \\
\text { (Wilkinson 1976; Tong 1985; Kweit and Kweit 1987). }\end{array}$ \\
\hline $\begin{array}{l}\text { Stakeholder } \\
\text { mobilization }\end{array}$ & $\begin{array}{l}\text { The ability of the stakeholder/citizen committee to } \\
\text { leverage internal and external support for its own } \\
\text { articulation of an ecosystem approach will affect adoption } \\
\text { (Baur 1977). The presence of an external change } \\
\text { agent can catalyze the lead agency to action (Rogers and } \\
\text { Shoemaker 1971; Zaltman et al. 1973; Rogers 1983). }\end{array}$ \\
\hline
\end{tabular}


TABLE 1 (Continued)

\begin{tabular}{|c|c|}
\hline Variables & Hypotheses \\
\hline $\begin{array}{l}\text { Shared } \\
\text { perceptions }\end{array}$ & $\begin{array}{l}\text { An organization's definition of a situation and the } \\
\text { nature of the problems to be solved shape the ways in } \\
\text { which new ideas are perceived (Burke 1979). Such } \\
\text { perception is based on shared premises and rules among } \\
\text { its members (Scott 1995) resulting from sustained } \\
\text { interaction and dialogue (Smirich 1985). The more } \\
\text { emphasis placed on building shared goals, expectations } \\
\text { and knowledge systems (Dalziel and Schoonover } \\
\text { 1988; Scott 1995), the more likely is adoption of an } \\
\text { innovation. }\end{array}$ \\
\hline $\begin{array}{l}\text { Organizational } \\
\text { networks }\end{array}$ & $\begin{array}{l}\text { Well-developed informal networks within and between } \\
\text { organizations enable more rapid communication of } \\
\text { new ideas and are more suited for adoption of innovation } \\
\text { (Rogers and Shoemaker 1971; Spence 1994). } \\
\text { Formal networks enhance implementation of the innovation } \\
\text { (Rogers 1983). }\end{array}$ \\
\hline $\begin{array}{l}\text { Agency } \\
\text { commitment } \\
\text { to citizen } \\
\text { participation }\end{array}$ & $\begin{array}{l}\text { If agency staff are open to fully involving stakeholders } \\
\text { in decision making, we would expect to see a more full } \\
\text { incorporation of citizen values and suggestions and changes } \\
\text { in decision making processes (Wilkinson 1976; } \\
\text { Grima 1985). Traditionally adversarial relationships } \\
\text { between citizens and government representatives in the } \\
\text { United States (Tong 1985) or traditional entrustment of } \\
\text { government bureaucracy with a "wide latitude of } \\
\text { administrative discretion" in Canada (Elliot 1981) } \\
\text { may influence agency and stakeholder roles (Susskind and } \\
\text { Cruikshank 1987). }\end{array}$ \\
\hline $\begin{array}{l}\text { Local } \\
\text { context }\end{array}$ & $\begin{array}{l}\text { Local political, economic, and legal conditions will affect } \\
\text { who is on the stakeholder committee and set } \\
\text { boundaries for adoption of significant perceptual and } \\
\text { institutional changes (Hall 1987; Kellogg 1993) that may } \\
\text { be needed for adopting an ecosystem approach. }\end{array}$ \\
\hline
\end{tabular}

developing the RAPs. Once the IJC and the governments agreed to use an ecosystem approach, it became incumbent on these organizations to complete the initiation stage, "matching" the IJC's articulation to agency practices and testing the innovation for its feasibility or appropriateness. Such an external change can be a powerful stimulus to innovation adoption (Rogers and Shoemaker 1971; Zaltman et al. 1973; Spence 1994). Organization members perceive a "performance gap" (Zaltman et al. 1973; Rogers 1983) or dissonance (Spence 1994) as they "match" the needed change with the existing structure and function of the organization. The implementation stage of the adoption process would occur as members of the organization identify the most appropriate response to the change to "close" the performance gap or "harmonize" dissonance. They would reinvent the innovation to accommodate the organization, but that process would change the organization as 
well, as members clarify and then routinize the innovation in the organization (Rogers and Shoemaker 1971).

As a result of a variety of internal and external variables, the innovation initiation and implementation process rarely occurs in neat, linear stages. It is often iterative, as the organizations involved each redefine, clarify, and routinize the innovation (Rogers 1983). The decentralized and open nature of the RAP processes, where RAPs are developed by different lead agencies in different locations in conjunction with local citizens, would make it likely that adoption of the innovation would follow such an iterative pattern. The innovation would be redefined (Rogers 1983) or tailored to suit local conditions (King and Anderson 1995), as lead agencies and community-based committees involved in the RAP process adopted an ecosystem approach as a conceptual framework and as a basis for assembling information appropriate for development of their RAP. Table 1 presents variables that might influence adoption of an ecosystem approach in remedial action plans. From the top, the variables are arranged from those affecting the lead agency, the advisory or stakeholder committee, the interaction between them, and the local context for the RAP process.

\section{Research Design}

\section{Case Study Site Descriptions}

To explore the adoption process, case studies were completed using guidance from Stake (1978) and Yin (1984) for RAP processes in two areas of concern: Hamilton Harbour and the Buffalo River. These two sites were chosen on the basis of four characteristics: differing political and cultural settings (Canadian and U.S.), differing administrative settings (a multidisciplinary provincial regulatory ministry and a state water quality division), two different types of areas of concern (present-day and historic industrial dominance), and similarities in timing (each was the first RAP process begun by the agencies).

Hamilton Harbour forms the far west end of Lake Ontario. The harbor's water and bottom sediments are polluted by municipal sewage treatment plant discharges, urban and rural non-point-source runoff, and industrial discharges, which add significant levels of nutrients, heavy metals, polynuclear aromatic hydrocarbons, and polychlorinated biphenyls (PCBs). The cities of Hamilton and Burlington and their suburbs have a total population of approximately 500,000 . Less than $5 \%$ of the harbor's shoreline is accessible to the public. The largest single agglomeration of steel-producing facilities in Canada lines the harbor's south shore, and the Royal Botanical Gardens line the north shore. The Canada Centre for Inland Waters, which houses several federal and provincial water-related departments and laboratories, is located on the sandbar that separates the harbor and Lake Ontario.

Running through the predominantly rural subbasins of its watershed, the Buffalo River enters Lake Erie a few hundred yards upstream from the Niagara River after flowing through metropolitan Buffalo. The urban population of the area has declined steadily in the last 20 years to about 300,000 . The lower river, designated as the area of concern, flows through nearly vacant adjacent urban land, once the site of large steel mills and other manufacturing facilities. Discharges from these industries contaminated lands along the river (some 325 sites) and river bottom sediments. Several municipal sewage discharge pipes, more than a dozen industries, and contaminated sediment "hot spots" still discharge a mixture of PCBs, chlord- 
ane, volatile organic substances, polynuclear aromatic hydrocarbons, and organic pathogens into the Buffalo River.

\section{Field Data Collection}

The objective for these cases was to determine the extent to which the RAP committees and lead agencies adopted an ecosystem approach to guide development of the draft RAP. Three field techniques were used: direct observation of participant interactions, document review, and personal interviews. I attended public information sessions, workshops, educational tours, and monthly citizen advisory committee meetings in the two case study sites for 2 years. Documents reviewed included reports on each area of concern issued by the International Joint Commission and the lead agency, full sets of minutes and handouts from advisory or stakeholder committee meetings, and draft reports and chapters of the remedial action plans as these were completed. I interviewed 35 stakeholder or advisory committee members and lead agency staff using a modified "guided interview" format (Patton 1980, 200; Mischler 1986), asking stakeholders and agency staff about goals and priorities for the RAP, environmental values, perceptions of the purpose of the citizen committee's work, and the working relationships among committee members and the agency staff. Agency staff were also asked about their routine roles and responsibilities, educational and professional experiences, their expectations for the RAP, and the activities being used to coordinate with other jurisdictions and agencies. This combination of field methods resulted in a holistic, context-focused approach that captured the complexity of the planning processes and changes in organizational behavior (Guba and Lincoln 1982; Peattie 1990).

\section{Case Studies and Analyses}

Each case study presented here describes how the initiation and implementation stages to adopt an ecosystem approach were influenced by a unique set of variables that impeded or supported that adoption.

\section{Hamilton Harbour}

The Ontario Ministry of the Environment (hereafter the Ministry) is responsible for developing the remedial action plan for Hamilton Harbour. In 1985, before the public was involved, the Ministry identified existing pollution problems in the harbor and presented a list of general management options. The driving force behind completion of the report came from then-provincial Minister of the Environment James Bradley, an early internal change agent committed to action on cleaning up the harbor as quickly as possible (Hamilton Harbour personal interview, 12 April 1989; all Hamilton Harbour interviews held in Hamilton, Ontario). Bradley changed the agenda of the Ministry of the Environment.

Past organizational incompatibility in the Ministry posed an initial impediment to adoption of an ecosystem approach. Scientific research on the harbor was traditionally segmented into discrete disciplines such as chemistry, biology, and physics. Each Ministry department, responding to its own policy mandate, used a relatively discrete pool of knowledge as the basis of research and policy development. This structural characteristic tended to preclude integrative research programs. As organized by the RAP coordinator, the early Ministry report for the RAP summarized results from all existing water-quality studies on the harbor and identified gaps in technical data. This beginning to the Hamilton Harbour RAP was the first 
attempt to integrate scientific data on the harbor across Ministry and department boundaries (Hamilton Harbour personal interview, 12 April 1989). A key step in the adoption process had been made as the coordinator began to test the feasibility of using an integrated information base to complete the RAP.

With additional funds provided by the Ministry, the RAP coordinator formed the RAP Writing Team and hired LURA--Land Use Research Associates of Toronto--to identify interested "stakeholders" in the area of concern. These stakeholders would develop a set of recommendations concerning water quality and uses that the Ministry would consider in developing the Hamilton Harbour RAP.

Three interrelated variables - the vision and technical capacity of the stakeholder committee members, the skills and expertise of the LURA facilitator, and the RAP coordinator's support for interdepartmental collaboration and stakeholder participation-supported clarification of an ecosystem approach to focus on an integrated conceptual and information base that lies at the heart of the IJC's ecosystem approach guidelines.

The stakeholder committee articulated its vision of what an ecosystem approach would entail: "a basin-wide approach to planning, research and management...including emphasis on holistic, coordinated management, a systems approach for managing flows of materials and energy, and [a] ... combined socialeconomic-environmental approach to problem-solving" (LURA 1986, 8-9). The stakeholder committee suggested expanding the spatial boundaries of the RAP from the harbor itself to the entire watershed, "a large region in the sense of an enlarged concept of home" (Ministry of the Environment 1988, 2). Its vision had an effect on the RAP. As one Ministry representative commented, "the original thinking was to treat [the RAP] as just a water quality issue, that the water quality had to be improved to a certain standard ... [Now] they are looking at the basin as a whole and how that's impacting on the harbor ... I think without the Stakeholders [the lead Ministry] wouldn't have done that" (Hamilton Harbour personal interview, 3 March 1990).

The technical capabilities of the stakeholders proved a catalyst to adoption as well. When forming the stakeholder committee, the facilitator from LURA sought out those stakeholders who had worked on long-standing environmental issues in the community, "the definition of entry" (Hamilton Harbour personal interview, 12 June 1989). Committee members included representatives from education, community groups, environmental and conservation groups, elected members of municipal government, business, industry, sailing and sport clubs, agriculture, recreation, the Harbour Commission, regional conservation authorities, and "citizens at large." This condition of prior activity toward improving harbor water quality ensured that members already had some knowledge about harbor water quality issues (Hamilton Harbour personal interview, 22 February 1990). Throughout the process the facilitator drew on and encouraged the technical capacity of community members, ensuring that all committee members shared and discussed technical information and participated in decisions on what information would be used as the basis of the RAP. A stakeholder from a local university commented that that process let the stakeholders "establish ... the kinds of studies that were necessary and what should go into the plan" (Hamilton Harbour personal interview, 21 April 1989). In this way the stakeholders began redefining and clarifying what and ecosystem approach meant for the community.

The Hamilton Harbour RAP was the first in Canada, the first time for the Ministry to attempt to adopt and implement an ecosystem approach. Both the 
stakeholders and the coordinator had redefined and clarified the innovation to include the need for joined interdepartmental and community cooperation to ensure the most integrated information base. The RAP coordinator played a critical role as an internal change agent. He negotiated relationships between the departments and the stakeholders to increase information integration. His efforts were supported by his office location at the Canada Centre for Inland Waters (the Centre). His proximity allowed him to build on existing informal and formal relationships to bring staff at the Centre into the RAP process. The coordinator's efforts to adopt a multidisciplinary information base required of an ecosystem approach were supported by the pool of information and technical expertise available at the Centre. The Centre became the vehicle through which an ecosystem approach was reinvented to mirror the organization's technical capacity.

The coordinator also agreed to the stakeholders' request to have nonlead Ministry technical staff on the committee as partners, unprecedented in Ministry public consultation processes. Many stakeholders commented in interviews that the presence of nonlead Ministry technical staff directly on the committee facilitated exchange of information and learning among the community members and increased the efficiency of the process when technical questions could be answered "on the spot" during meetings. The close contact between stakeholders and the nonlead agency staff serving together on the committee enabled the participants to adopt an information base that integrated scientific disciplines and public values, a key constituent of an ecosystem approach.

As the RAP progressed, the coordinator acted as an advocate in the Ministry for the stakeholders' wish to integrate broader socioeconomic and scientific considerations required of an ecosystem approach. Said one stakeholder, "[the coordinator] is ... not considered to be the 'agency man"' (Hamilton Harbour personal interview, 22 February 1990), and most of the participants interviewed considered the coordinator's role a positive one, confident in his commitment to incorporating their wishes about an ecosystem approach into the RAP.

Adopting an ecosystem approach required increased interagency cooperation and flexibility. The coordinator's leadership brought other federal and provincial stakeholders into the process. The facilitator structured the public involvement as participation by likely implementors. These strategies led to reconfigured informal organizational arrangements, as diverse organizations and agencies came together to work on the RAP. The dialogue managed by the facilitator among the stakeholders and Ministry to arrive at full consensus for each decision increased the level of shared perceptions and understandings and enhanced clarification of the requirements of an ecosystem approach. This clarity led participants to implement water quality improvements recommended for the harbor in the RAP before the RAP was finished. Provincial agencies, local jurisdictions, and the private and nongovernmental organizations came together to address system-wide sources of water pollution, implement joint research projects on waste treatment technologies, and restore a marsh area at the western end of the harbor. The coordinator, who had developed good working relationships with the steel companies prior to the RAP, reported that the companies would assist in restoration of a harbor inlet burdened with highly toxic sediments adjacent to their facilities. As the RAP process entered its third year, the stakeholders began efforts to link the benefits of cleaner water to efforts to improve quality of life in the communities around the harbor. The city of Hamilton and its chamber of commerce increased efforts to develop public green space and water-oriented recreation opportunities as part of their participation in 
the RAP. There is little doubt that the RAP stimulated the city of Hamilton to reframe its planning to focus on sustainability, incorporating the city's perception of the carrying capacity of Hamilton Harbour and its watersheds.

These joint projects and programs were begun shortly after the RAP process began and long before a draft RAP was completed. From 1989 through 1992 stakeholders and implementors in the Hamilton region spent over \$205 million (Canadian) on research, restoration, and pollution abatement in the harbor. The joint projects were the culmination of the adoption of an integrative decisionmaking and implementation model required of an ecosystem approach.

The iterative nature of the innovation adoption process is well illustrated by the cooperation that led to these restoration and research projects. The first remedial actions taken focused on filling the "gaps" in the information on the harbor's water quality. This led the participants to focus on discharges from wastewater treatment plants. Research on a new filtration technology, advocated by the Ministry but at first bemoaned by the stakeholder committee, resulted in substantial improvements in the effluent quality from a relatively inexpensive technological change. This improvement led to an emphasis on restoration of the harbor's shoreline wetlands as means to further improve pollutant filtration. The stakeholders mobilized local organizations to work with the Ministry to increase exchange of information and form new cooperative partnerships. As the participants learned more about how the harbor functioned, their focus shifted accordingly, integrating information and choosing new remedial actions. They began to incorporate flexible decision making, "which changes to meet new challenges in a creative and appropriate manner over time as circumstances changes and knowledge increases" (Donaldson 1989, 3). They increasingly saw the harbor as a total system, not just a body of water whose water quality needed "fixing."

The local cooperation to implement early recommendations of the RAP embodied the integrated and flexible planning and management that constitute a key component of the IJC's articulation of the ecosystem approach. Adoption of an ecosystem approach changed RAP organizations and their networks. The stakeholders' adoption emphasized informal institutional (rather than legal) changes to secure the cooperation of the implementors and to gain political support from the general public to implement the RAP. The Ministry staff working on the RAP began to see that partnerships with stakeholders enhanced the Ministry's capacity to meet its own mandates and objectives. The variables most strongly affecting this arrangement were the Ministry's commitment to a strong community role despite little historic experience prior to the RAP, the ability of the stakeholder committee to mobilize support for the RAP in their organizations, and a shift in the locus of impulse from the Ministry's upper levels to the local RAP participants. As they began to take ownership of the process and articulate their own ecosystem approach to meet local conditions and priorities, the participants routinized an ecosystem approach, implementing its adoption as an innovation in continued planning and community participation.

\section{The Buffalo River}

The Buffalo River RAP powerfully illustrates the influence of an external change agent on the innovation adoption process. Little evidence exists that the New York Department of Environmental Conservation (hereafter the Department), the lead 
agency responsible for developing the Buffalo River RAP, would have initiated or implemented an ecosystem approach without the influence of the Buffalo River Citizen Committee (hereafter the Citizen Committee). Fiver interrelated variables significantly influenced the ability of the Citizen Committee to initiate and implement an ecosystem approach: its effective mobilization, a perception shared with the Department that the Buffalo River needed significant improvements, the lack of Department resources for completing the RAP, the overall incompatibility of the Department's structure and function to the information demands of an ecosystem approach, and the technical skills of the Citizen Committee.

The initiation stage to adopt an ecosystem approach for the Buffalo River RAP began when Great Lakes United (GLU), an advocacy group in the basin, held a press conference it called a "Citizen Hearing on the Great Lakes" to focus attention on water pollution in the Buffalo River Area of Concern. Eleven area community advocates presented a letter to the Department Commissioner at the press conference, requesting that a citizen's committee be formed to work with state officials on a remedial action plan. In sharp contrast to the level of organization by the committee, the Department had barely begun its programs for the RAP and had no set plan for public involvement. One member perceived an inherent reluctance by the agency to work with the public. "My sense of the State is that it is reluctant to get involved in public participation. [They] do it when forced to do it, they will not voluntarily proceed. ... The [Department] philosophy [makes it] reluctant to include citizens" (Buffalo River personal interview, 6 February 1990; all Buffalo River interviews held in Buffalo, NY). The letter's public presentation changed the external environment of the Department, creating a performance "gap." As one Citizen Committee member noted, "It was classic community organizing, petitioning government for the redress of grievances, and it created a pressure that the Department of Environmental Conservation could not ignore" (Boyer 1988, 2).

The Department Commissioner responded by inviting community members to the state capital where they worked out a framework for beginning the RAP with community involvement, an early effort to test the feasibility of citizen participation requirements of an ecosystem approach. Twenty-one people were appointed to form the Citizen Committee, including five members from the original petitioning group (Buffalo River personal interview, 17 February 1990); but as another Citizen Committee member said, "the committee was in place and running before DEC [Department of Environmental Conservation] appointed anyone" (Buffalo River personal interview, 6 February 1990).

The Department and the Citizen Committee shared the perception that the river was in desperate need, and both were committed to solving the pollution problems in the river (Buffalo River personal interview, 6 February 1990). The shared perception gave the Citizen Committee an opportunity to catalyze the agency to test an ecosystem approach for its appropriateness for the Buffalo River RAP. Despite such a perception, no "organizational slack" existed for the RAP. The Department staff declared early in the process that they had no additional resources for the RAP. For the most part, work activities for the RAP were added to regular duties of the local Water Division staff at the Region 9 Office in Buffalo, and resources for the RAP had to be "pirated" from existing programs. In the Buffalo River RAP, it was the lack of agency resources that allowed the Citizen Committee to redefine its role from community constituents who only demanded a particular service to partners who could offer resources and information. The Citizen Committee then was able to influence what an ecosystem approach for the RAP would entail. 
The Citizen Committee defined an "ecosystem approach" as the need for integrated information on the biochemical and physical conditions of the river (including its riparian corridor, adjacent lands, and watershed), analysis of how local land use and economic development planning objectives might affect restoration of the river, and changes to existing administrative Department programs. The administrative mandate of the Department Water Division proved incompatible to the ecosystem approach articulated by the Citizen Committee. The Department staff countered that their responsibilities were limited to a focus on the chemical status of the water column itself; that policy on land use and economic development was a local government responsibility and therefore beyond the scope of the RAP; and that the Department would follow requirements of the Clean Water Act (their legal mandate) in setting policy and administrative programs for the RAP. Thus far the "matching" process did not support adoption of an integrated information base required of an ecosystem approach.

Citizen Committee members acknowledged that the Department's function and structure were incompatible with the committee's expectations for the RAP: This has to be "different from how programs have been traditionally run ... with a disciplinary wall [between parts of the agency. It] implies a substantial shift in data gathering efforts...cooperation between water quality and fish and wildlife [people] in DEC, and between various agencies ... to ultimately get where the RAPs are supposed to go" (Buffalo River personal interview, 7 February 1990).

How would the Citizen Committee catalyze the Department to at least test the ecosystem approach as a framework for the RAP despite apparent incompatibilities? They offered the technical skills that the Department needed. Some of the committee members were experts in water systems computer modeling, aquatic biology, water quality regulation and law, and land use planning. Prior to the RAP, some technical information on the river had been gathered by county, state, and federal agencies over the previous several decades, but this information was housed in separate databases and locations. No comprehensive understanding of the condition of the river existed. The Citizen Committee Technical Subcommittee assembled maps, researched remedial technologies, and organized workshops for Citizen Committee members and agency staff. They brought in scientists from academia and other agencies, serving to build a shared knowledge base for the RAP. The subcommittee then spent hundreds of hours working alone and with Department water division staff to integrate three separate databases into one in order to generate a more complete picture of conditions on the river. This database would eventually be used by the Department in monitoring programs recommended in the RAP (Department of Environmental Conservation 1989). The agency staff relied on the Citizen Committee for technical expertise and time to analyze and systematize data on the river. The agency couldn't afford to hire consultants, and therefore relied heavily on the committee members for the necessary information and expertise. The Citizen Committee could work at par with the agency staff on many technical issues, and their technical capabilities allowed them to define the information base used in developing the RAP as one jointly created. Citizen Committee members considered expanding the knowledge base for the RAP an important part of their role in the planning process. As one member said, "The purpose of the committee was ... to give DEC a broader perspective, a multi-faceted view ... . [The RAP allowed us to] get others involved who are outside the regular power of DEC, to push the discussion beyond [the normal focus]" (Buffalo River personal interview, 6 February 1990). The committee redefined an ecosystem approach to include a more inte- 
grative knowledge base and greater community participation.

The Citizen Committee was not as successful in catalyzing change to formal institutional arrangements in the Department, however. The sometimes arduous process to evaluate the status of the IJC use impairments in the RAP process illustrates the iterative nature of matching and redefining an innovation. According to the IJC, the RAPs are to identify water-quality problems through scientific study and recommend remedial actions. The Department uses the New York State surface water classification system as the basis of assessing the status of a particular body of water. Each surface water body is assigned a letter classification designating the "best usage of waters," and at the time the RAP process began, the Buffalo River was classified "D," the lowest rating, indicating the water was too polluted for use as a drinking water source, for fish propagation, or for primary and secondary contact recreation (Department of Environmental Conservation 1986). The Buffalo River had been relegated to status as an industrial sewer. The Department's staff were most concerned with fulfilling their legal obligation to manage their water discharge permit processes to meet the river's current use classification under the state system.

In contrast, Citizen Committee members argued that an ecosystem approach as embodied in the IJC 14 beneficial uses was the proper framework by which to assess the river's condition and set goals for restoration. They argued that the state water classification system was inadequate for the purposes of the RAP because it did not take into account ecosystem conditions and was basically "a license to pollute" (Buffalo River personal interview, 31 January 1990). For the Buffalo River Citizen Committee, an ecosystem approach required returning the river to the cleanest, most ecologically healthy state, to allow for all types of uses, human and nonhuman.

The Department continually "matched" Citizen Committee expectations to the agency's on each issue, judging its appropriateness or compatibility with agency operations. To the extent an ecosystem approach coincided with its present responsibilities, the Department was willing to innovate. The Citizen Committee members had to concede that the Department would most likely develop and implement the RAP using the state water classification system. What could the Citizen Committee do? As one member has recalled, the committee used "a two track strategy" (Boyer and McMahon n.d.): While emphasizing an ecosystem approach in what changes were needed in the river, the committee argued that a critical remedial action for the Buffalo River was to change its classification rating. The Department eventually agreed that a change was necessary.

The Citizen Committee wanted the river reclassified to a " $B$ " rating (which would restore the water to support restoration of fish propagation and not pose a risk to primary human contact). The Department staff argued that a class " $C$ " rating was an appropriate designation for the Buffalo River because its current use as a navigation channel made swimming and fish habitat restoration virtually impossible. In the end, the Department position prevailed. A short time after the RAP was submitted to the International Joint Commission for review, and after the Citizen Committee had been dissolved, the state announced that the river would be reclassified to a class "C" stream.

The Citizen Committee and Department had clarified an ecosystem approach as best they could given the existing system of standards and Department mandates. This clarification did not impede adoption of a more integrated information base, but largely precluded the integrative social, economic, and political information and changing institutional frameworks that would routinize the innovation. Many Citizen Committee members interviewed expressed frustration that the Department 
was reluctant to break out of its traditional water quality regulatory function, which was exactly what was needed in order to implement fully a comprehensive ecosystem approach to develop the RAP. Today a second community-based technical advisory committee continues to advocate that the Department implement the RAP using an ecosystem approach. A not-for-profit advocacy group formed by several Citizen Committee members continues its efforts to build community support for their vision of full restoration of the Buffalo River and redevelopment of its adjacent lands and neighborhoods. Both efforts are a testimony to the continuing importance of the citizens' vision and actions to adopt an ecosystem approach in the joint community-Department effort to implement the Buffalo River RAP.

\section{Summary and Conclusions}

\section{Congruence with IJC Articulation}

How (to what extent and in what ways) did lead agencies and RAP committees adopt the integrative information base required by an ecosystem approach as articulated by the IJC? The level of congruence differed between the sites, but both lead agencies made some progress toward adoption of an integrative information base. Such movement led them to build interconnected and integrative data bases to identify biological-physical-chemical conditions in the Area of Concern and evaluate use impairments more comprehensively. However, an ecosystem approach that included socioeconomic concerns proved extremely difficult, particularly for the Buffalo River RAP.

Lead agency adoption of an integrated information base precipitated changes in the agencies and in their relationships with stakeholders and citizens. For example, as the agency and committee learned what information could be retrieved by the agency and what needed to be obtained from other organizations, including the citizens, each gained a better appreciation of their interdependence and the need to cooperate if they were to implement an ecosystem approach. A variety of variables and conditions, described earlier, shaped citizen roles at each site. By striving to adopt an ecosystem approach that had been articulated through their dialogue with citizens, the agencies sought or were compelled by their needs to enhance the participation of stakeholders.

\section{Adoption Process}

These two cases illustrate that adoption of an innovation does not occur in a neat, linear process. In each stage developing the RAP the agency and the committee considered what an ecosystem approach meant and how it should be operationalized: Was an ecosystem approach relevant? Did it match the available resources and authority? How would its implementation change decision making? What would be required for its implementation? In each case, the stages of adoption (agenda setting, matching, redefining, clarifying, and routinizing) occurred again and again, even simultaneously, through each particular stage of the RAP planning process.

These cases illustrate how adoption of an integrative conceptual framework shaped decisions. The participants' understanding of what they meant by an ecosystem approach changed as they learned from each other what each envisioned and expected and arrived at consensus on their definition. Their understanding in turn structured their perceptions of what information was needed. As they gained greater 
knowledge of technical issues, they could further clarify what they meant by an ecosystem approach. Such a reciprocal process is an important characteristic of their experiences and supports assertions that citizens and agency staff members must have flexibility in planning process to adopt evolving normative emphases as technical (ecological) knowledge improves (Hartig and Law 1994).

\section{Variables Infuencing Adoption}

In each case, adoption of an ecosystem approach was shaped by a complex constellation of interdependent variables and conditions, which either existed prior to the RAP or were created through the RAP planning process. Table 2 summarizes the influences of the adoption variables for each case. Which variable(s) proved most significant was a product of their mutual interaction and their influence on the RAP planning process.

In Hamilton Harbour, several interacting variables proved highly supportive to adoption of an integrated information base. The locus of innovation was from within the Ministry, although at a higher organizational level. The minister's advocacy changed the mandate of the regional branch that would develop the RAP. The leadership of the RAP coordinator as a change agent was critical in Hamilton Harbour. He was highly motivated toward adopting a systemic knowledge base and expanded partnerships with community stakeholders. The commitment of the local Ministry staff to citizen participation was supported by participation guidelines issued by the Ontario Ministry of the Environment. The facilitator's use of a consensus-based decision rule, rather than a majority vote, supported adoption of an ecosystem approach as well, in that it meant stakeholders spent more time listening to each other than they might have with a simple voting process. They were able to more fully appreciate the innovation's importance and understand how it could be implemented. Finally, the level of technical expertise assembled by the Ministry from the Centre for Inland Waters and on the stakeholder committee facilitated the interdisciplinary and interorganizational exchange of information critical to adopting an ecosystem approach.

By far the most important variables supporting adoption of an ecosystem approach in the Buffalo River RAP were the technical expertise and mobilization of the members of Buffalo River Citizen Committee. Their technical knowledge overcame the lack of agency expertise and resources. Their mobilization changed the agency's approach to citizen participation for the RAP.

The role of the lead agency was quite different in the two cases. Lead agencies, because they are vested with the authority for the RAP planning process, hold profound power to shape the process, its substantive content, and who participates. In the Hamilton Harbour case, the Ontario Ministry of the Environment supported and facilitated adoption of an ecosystem approach as a framework for development of the RAP. The commitment and openness of the Ministry to community participation facilitated a strong partnership role for the stakeholder committee. As we saw in the Buffalo River case, however, a lack of agency openness does not preclude strong influence by citizens. Other variables-citizen mobilization and technical expertise-allowed citizens there to define their own role, perforating some of the barriers to an ecosystem approach and to citizen participation that the agency perceived or created during the process.

In both cases, the role of citizen stakeholders was a critical variable shaping adoption of an ecosystem approach, supporting Hartig and Vallentyne's (1989) 


\section{ADOPTING AN ECOSYSTEM APPROACH}

TABLE 2 Influences of adoption variables of case study RAPs

\begin{tabular}{|c|c|c|}
\hline Variables & Hamilton Harbour & Buffalo River \\
\hline Locus of impulse & Within Ministry; strong during agenda setting & Absent from agency; initially impeded matching \\
\hline Compatibility & $\begin{array}{l}\text { Existing functions moderately compatible, } \\
\text { moderately supports matching and redefining }\end{array}$ & $\begin{array}{l}\text { Agency structure and function highly } \\
\text { incompatible, impedes matching and redefining }\end{array}$ \\
\hline Technical expertise & $\begin{array}{l}\text { Access enhanced by presence of Centre for } \\
\text { Inland Waters; strongly supports redefining and } \\
\text { clarifying }\end{array}$ & $\begin{array}{l}\text { Agency expertise lacking; initially impedes } \\
\text { clarifying substage, but overcome by citizen role }\end{array}$ \\
\hline Process skills & $\begin{array}{l}\text { RAP coordinator and facilitator skills strongly } \\
\text { support redefining and clarifying stages }\end{array}$ & Little influence on adoption process \\
\hline $\begin{array}{l}\text { Agency } \\
\text { organizational slack }\end{array}$ & $\begin{array}{l}\text { Increase in funds for facilitator and additional } \\
\text { research strongly supports clarifying and } \\
\text { routinizing stages }\end{array}$ & $\begin{array}{l}\text { Little or no increase in resources } \\
\text { (ultimately supports adoption vis-à-vis citizen } \\
\text { role) }\end{array}$ \\
\hline $\begin{array}{l}\text { Stakeholder technical } \\
\text { expertise }\end{array}$ & $\begin{array}{l}\text { High level strongly supports matching, redefining } \\
\text { and clarifying stages }\end{array}$ & $\begin{array}{l}\text { High level and key variable supporting redefining } \\
\text { and clarifying }\end{array}$ \\
\hline $\begin{array}{l}\text { Stakeholder } \\
\text { mobilization }\end{array}$ & $\begin{array}{l}\text { Little influence initially, but key during } \\
\text { routinization substage }\end{array}$ & $\begin{array}{l}\text { High level was key in establishing citizen role to } \\
\text { support initiation and implementation stages }\end{array}$ \\
\hline $\begin{array}{l}\text { Shared } \\
\text { perceptions }\end{array}$ & $\begin{array}{l}\text { High emphasis on consensus building strongly } \\
\text { supports redefining and clarifying stages }\end{array}$ & $\begin{array}{l}\text { Efforts to create shared knowledge base through } \\
\text { workshops and dialogue supports redefining } \\
\text { and clarifying stages }\end{array}$ \\
\hline $\begin{array}{l}\text { Organizational } \\
\text { networks }\end{array}$ & $\begin{array}{l}\text { Preexisting interagency networks strengthened, } \\
\text { strongly supports clarifying and routinizing } \\
\text { substages }\end{array}$ & $\begin{array}{l}\text { New community and interagency networks } \\
\text { support clarifying substage }\end{array}$ \\
\hline $\begin{array}{l}\text { Citizen } \\
\text { participation }\end{array}$ & $\begin{array}{l}\text { High level of Ministry commitment strongly } \\
\text { supports entire implementation process }\end{array}$ & $\begin{array}{l}\text { Initial agency reluctance impedes initiating } \\
\text { stage; overcome by strong citizen role }\end{array}$ \\
\hline $\begin{array}{l}\text { Local } \\
\text { context }\end{array}$ & $\begin{array}{l}\text { Existing Ministry relationship with industry } \\
\text { strongly supports entire implementation stage }\end{array}$ & $\begin{array}{l}\text { Lack of industrial activity on river and absence } \\
\text { on Citizen Committee supports redefining as per } \\
\text { citizen perspective }\end{array}$ \\
\hline
\end{tabular}


claim that the key to using an "ecosystem approach" is a citizen committee. Citizen participation supported adoption of an ecosystem approach in principle by fulfilling the IJC's guidelines for public involvement. In these cases, citizens and stakeholders supported the implementation stages of adoption through their partnership roles, influencing how an ecosystem approach was redefined and clarified and how it was routinized as an influence in decision making for development of the draft RAP.

At Hamilton Harbour we see a Ministry committed to a citizen role firmly integrated into the RAP process, despite the Ministry's relative inexperience. Citizen members on the stakeholder committee responded by asking that nonlead Ministry staff be included on their committee as partners. These events would seem to support the notion that a history of nonadversarial relationships facilitated the organizational interaction critical for adopting an ecosystem approach. For the Buffalo River case, we saw an agency with a long history of legally mandated citizen participation that, until the Citizen Committee, had been predominantly informing citizens about agency actions. The RAP process began with a high level of mistrust, but through long hours of dialogue over technical issues "a lot of good will was gained by listening and having respect" (Buffalo River personal interview, 7 February 1990). The organizations' shared commitment to improving the river, which became clear through the long hours of interaction between the Department staff and the Citizen Committee members, was the basis of the respect that developed between the agency and the community. However, it was the vision, commitment, and initiative of the Citizen Committee members that transformed public participation into community action and opened a wedge into the agency's normal routines, moving the agency toward adoption of an ecosystem approach.

\section{References}

Baur, E. 1977. Mediating environment disputes. Western Sociology Rev. 8:16-24.

Boyer, B. 1988. Remedial action planning and environmental conflict. Paper presented at Conference on Remedial Action Plant Program, Syracuse University, Syracuse, NY, September.

Boyer, B., and J. McMahon. n.d. "A two-track strategy" for the Buffalo River Remedial Action Plan. Unpublished paper, Baldy Center for Law and Social Policy, SUNY at Buffalo Law School, Buffalo, NY.

Burch, W., and D. DeLuca. 1984. Measuring the social impact of natural resource policies. Albuquerque: University of New Mexico Press.

Burke, C. 1979. Innovation and public policy. Lexington, MA: Lexington Books.

Caldwell, L. 1988. Implementing an ecological systems approach. In Perspectives on ecosystem management for the Great Lakes, ed. L. Caldwell, 1-29. Albany, NY: State University of New York Press.

Dalziel, M., and S. Schoonover, 1988. Changing ways. New York: American Management Association.

Department of Environmental Conservation 1986. Water quality regulations: Surface water and ground-water classifications and standards, Part 701.19. Albany, NY.

-1989. Buffalo River Remedial Action Plan (draft). Albany, NY.

Desveaux, J., E. Lindquist, and G. Toner. 1994. Organizing for policy innovation in public bureaucracy: AIDS, energy and environmental policy in Canada. Can. J. Polit. Sci. XXVII (3, September):493-528.

Dockstator, J. 1990. The use of public advisory committees in environmental planning: A case study analysis. Uniform Resource Locator: http:freenet.vancouver.bc.ca/loc.../wcel/ otherpub/fearo/5151_1-2.html. 
Donaldson, C. 1989. The Remedial Action Plan for Hamilton Harbour: Land use and ecosystem planning perspectives. Handout at Stakeholder Committee meeting. Hamilton, Ontario: RAP Coordinator, Canada Centre for Inland Waters.

Elliot, J. 1981. The sociology of natural resources. Toronto: Butterwork.

Great Lakes Science Advisory Board. 1978. The ecosystem approach. Windsor, Ontario: International Joint Commission.

-1989. Report of the Great Lakes Science Advisory Board to the International Joint Commission. Windsor, Ontario: International Joint Commission.

Grima, L. 1985. Participatory rites: Integrating public involvement in environmental impact assessment. Toronto: Institute for Environmental Studies. University of Toronto.

Guba, E., and Y. Lincoln. 1982. Epistemological and methodological bases of naturalistic inquiry. Educational Communication Technol. J./30(winter):233-252.

Hall, R. 1987. Organizations: Structures, processes and outcomes. 4th ed. Englewood Cliffs, NJ: Prentice Hall.

Hartig, J., and N. Law. 1994. Progress in Great Lakes Remedial Action Plans: Implementing the ecosystem approach in Great Lakes Areas of Concern. Document 905-R-24-020. Washington, DC: U.S. Environmental Protection Agency.

Hartig, J., and J. Vallentyne. 1989. Use of an ecosystem approach to restore degraded areas of concern in the Great Lakes Basin. Ambio 18(8):423-428.

International Joint Commission. 1978. The ecosystem approach. Research Advisory Board Report to the International Joint Commission. Windsor, Ontario.

- 1989. Great Lakes Water Quality Agreement and 1987 Protocol. Washington, DC and Ottawa, Ontario: International Joint Commission.

Kellogg, W. 1993. Ecology and community in the Great Lakes basin: The role of stakeholder and advisory committees in environmental planning processes. Dissertation, Cornell University, Ithaca, NY.

King, N., and N. Anderson. 1995. Innovation and change in organizations. London: Routledge.

Kweit, M., and R. Kweit. 1987. The politics of policy analysis: The role of citizen participation in analytic decision making. In Citizen participation in public decision making, eds. J. DeSario and S. Langton, 19-37. New York: Greenwood.

Landre, B., and B. Knuth. 1993. Success of citizen advisory committees in consensus-based water resources planning in the Great Lakes Basin. Society and Natural Resources 6(3):229-257.

Landre, B., B. Knuth, and C. O'Neill. 1990. Public participation in Great Lakes Remedial Action Planning. Final Report, New York Sea Grant Extension/College of Agriculture and Life Sciences Applied Research Program, Cornell University, Ithaca, NY.

Land Use Research Associates. 1986. Hamilton Harbour's water quality. The stakeholders' proposals. Toronto, Ontario: LURA.

MacKenzie, S. 1993. Ecosystem management in the Great Lakes: Some observations from three RAP sites. Int. J. Great Lakes Res. 19(1):136-144.

Ministry of the Environment 1988. Goals, problems and options report. Hamilton Harbour Remedial Action Plan. Toronto: Ontario Ministry of the Environment.

Mischer, E. 1986. Research interviewing: Context and narrative. Cambridge, MA: Harvard University Press.

Mohr, L. 1969. Determinants of innovation in organizations. Am. Polit. Sci. Rev. 63:111-126.

National Research Council and Royal Society of Canada. 1985. The Great Lakes Water Quality Agreement: An evolving instrument for ecosystem management. Washington, DC: National Academy Press.

Patton, M. 1980. Qualitative evaluation methods. Newbury Park, CA: Sage.

Peattie, L. 1990. Anthropology and planning. J. Planning Education Res. 9(2):101-106.

Pollution from Land Use Activities Reference Group. 1978. Environmental management strategy for the Great Lakes system. Windsor, Ontario: International Joint Commission.

Rogers, E. 1983. Diffusion of innovations. 3d ed. New York: Free Press.

Rogers, E., and F. Showmaker. 1971. Communications of innovations. New York: Free Press. 


\section{ADOPTING AN ECOSYSTEM APPROACH}

Scott, W. 1995. Introduction: Institutional theory and organizations. In The institutional construction of organizations: International and longitudinal studies, eds. W. Scott and S. Christensen, xi-xx. Thousand Oaks, CA: Sage.

Smirich, L. 1985. Is the concept of culture a paradigm for understanding organizations and ourselves? In Organizational culture, ed P. Frost, 55-72. Beverly Hills, CA: Sage.

Spence, W. R. 1994. Innovation: The communication of change in ideas, practices and products. London: Chapman \& Hall.

Stake, R. 1978. The case study method in social inquiry. Education Rev. (February):5-8.

Susskind, L., and J. Cruikshank. 1987. Breaking the impasse. New York: Basic Books.

Tong, R. 1985. Ethics in policy analysis. Englewood Cliffs, NJ: Prentice Hall.

Wilkinson, P. 1976. Public participation in environmental management. In Natural resources for a democratic society: Public participation in decision making, eds. A. Utton, W. R. Sewell, and T. O'Riordan, 117-135. Boulder, CO: Westview.

Yarbrough, C. 1985. Multi-institutional management: The Green Bay experience. Report to the Great Lakes Science Advisory Board. Windsor, Ontario: International Joint Commission.

Yin, R. 1984. Case study research. Beverly Hills, CA: Sage.

Zaltman, G., R. Duncan, and J. Holbek, 1973. Innovations and organizations. New York: Wiley. 